\title{
Factors Associated with Intimate Partner Violence among Wives of Military and Civilian Men in Abuja Nigeria
}

\author{
Prosper Obunikem Uchechukwu Adogu ${ }^{1,2^{*}}$, Uzoamaka Carol Chimah', Amobi Linus Ilika1,2, \\ Chika Florence Ubajaka ${ }^{1,2}$ \\ ${ }^{1}$ Department of Community Medicine and PHC, Nnamdi Azikiwe University, Nnewi, Nigeria \\ ${ }^{2}$ Department of Community Medicine and PHC, Nnamdi Azikiwe University Teaching Hospital, Nnewi, Nigeria \\ ${ }^{3}$ Medical Department, Ministry of Defence Headquarters, Abuja, Nigeria \\ Email: "prosuperhealth@yahoo.com
}

Received 5 January 2015; accepted 21 January 2015; published 29 January 2015

Copyright (C) 2015 by authors and Scientific Research Publishing Inc.

This work is licensed under the Creative Commons Attribution International License (CC BY).

http://creativecommons.org/licenses/by/4.0/

c) (i) Open Access

\section{Abstract}

Intimate partner violence (IPV) constitutes transgression of gender norms especially in patriarchal societies such as Nigeria where women are expected to be seen and not heard. The purpose of this study was to determine the factors associated with IPV among women in civilian and military settings. A comparative cross sectional study of 260 eligible women married to military and civilian partners (130 on either side), was selected using a multi-stage sampling technique. Data were collected on personal variables and types of IPV experienced. Relationship between the different forms of IPV and the respondents' personal and partner characteristics in the two populations were compared using Chi square and significant $p$-value set at $\leq 0.05$. Multiple logistic regression analysis was used to predict the outcome of the independent variables. Partner alcohol consumption $(p=\mathbf{0 . 0 0 4}, 0 \mathrm{R}=2.8)$, partner physical fight with another man $(p=$ $0.009, \mathrm{OR}=3.1)$ and quarrels in intimate relationship $(p=0.002 ; \mathrm{OR}=29.7)$ were all significant predictors of emotional violence. Also belonging to Yoruba ethnic group $(p=0.043,0 R=4.31)$ and being married for $>2$ years but $<10$ years $(p=0.001,0 R=4.02)$ significantly predict physical violence. Moslem women were at a higher risk $(p=0.000,0 \mathrm{R}=5.23)$ of experiencing sexual violence compared to respondents of other religions. Unskilled respondents were over five times at higher risk of experiencing sexual violence than their skilled counterparts; $(p=0.024,0 R=5.52)$. Similarly, alcohol consumption by respondent's partner was a significant predictor of sexual violence among the respondents, $(p=0.012)$. Family value re-orientation to address traditional norms of negative unbalanced patriarchy should be pursued with renewed vigor. Alcohol and hard drugs use should be discouraged among men who must be informed to understand that the abuser of

*Corresponding author.

How to cite this paper: Adogu, P. O. U., Chimah, U. C., Ilika, A. L., \& Ubajaka, C. F. (2015). Factors Associated with Intimate Partner Violence among Wives of Military and Civilian Men in Abuja Nigeria. Sociology Mind, 5, 61-73.

http://dx.doi.org/10.4236/sm.2015.52007 
today is a father of the abused tomorrow.

Keywords

Factors, Intimate Partner Violence, Wives, Military, Civilian, Abuja, Nigeria

\section{Introduction}

Violence against women is a universal phenomenon that persists in all countries of the world affecting the lives of millions of women worldwide irrespective of their socio-economic status (WHO, 1997).

IPV is driven by some societal norms like patriarchy, power relations, hierarchical construction of masculinity and feminity all of which predicate on control of women resulting in structural gender inequality (Thaler, 2011). Evidence has shown from studies worldwide that certain events are consistent "triggers" of IPV. These include not obeying husband, refusing to have sex when the husband wants it, questioning him about girlfriend/mistress or expressing suspicion of infidelity, talking back at husband, not taking care of children or home, issues about money, food not being ready on time or going out without husband's permission (Bradley, 1985; Schuler et al., 1996; Hindin et al., 2002). All of these constitute transgression of gender norms especially in patriarchal societies (Nigeria inclusive) where women are expected to be seen and not heard. Among South-Asian women in the USA, problems with in-laws were reported as a major cause of IPV (Maziak et al., 2003), while in Europe, causes such as economic hardship (18.9\%), alcohol consumption by male partner (18.5\%) and inadequate relationship with family (15.8\%) (Usta et al., 2007) were held responsible. Philippine women reported causes of IPV as talking back to spouse (27\%), nagging husband (24\%), jealousy by husband (18\%), husband drunk (13\%), issues with conception (9\%) and the remaining 10\% gave multiple reasons (Maziak et al., 2003). Ilika and his colleagues in Nigeria reported economic demand (56.1\%), reproductive issues (42.5\%), alcohol and drugs (61.2\%) as perceived reasons for IPV among women of childbearing age attending a primary healthcare centre in Eastern Nigeria (Ilika et al., 2002).

Several factors can increase the risk that someone will hurt his or her partner. However, having these risk factors does not always mean that IPV will occur. Certain risk factors have been highly associated with perpetration of IPV; such as using hard drugs or alcohol, especially drinking heavily, witnessing or being a victim of violence as a child and not having a job, which can cause feelings of stress. Studies have also identified certain socio-demographic and cultural factors that might protect or put women at greater risk of intimate partner violence (Jewkes et al., 2002; Thurston et al., 2006; Vest et al., 2002).

In the WHOMCS study, younger ever-partnered women, especially those aged 15 to 19 years, were at higher risk of "current" (within the past 12 months) physical or sexual violence or both by a partner in all settings except Japan and Ethiopia. In urban Bangladesh, 48\% of 15 - 19-year-old women reported current physical or sexual violence, or both compared to $10 \%$ of 45 - 49 year-olds. In urban Peru, the finding was $41 \%$ among 15 - 19 years old compared to $8 \%$ of 45 - 49 years old. This study also revealed in part the pattern that younger men tend to be more violent than older men, and that violence tends to start early in many relationships. In some settings younger women may be living together with their partners out of wedlock which is associated with higher levels of violence. Also in some settings, older women have greater status than young women, and may therefore be less vulnerable to violence. Similarly, studies in America revealed that women of age group 20 - 24 years have the greatest risk for IPV (CDC, 2012; Thurston et al., 2006; Vest et al., 2003).

In all but two settings in the WHOMCS, women who had been separated or divorced reported much more partner violence during their lifetime than currently married women (the exceptions were provincial Bangladesh and Ethiopia, where the proportion of divorced or separated women is relatively low in the general population). There was also more partner violence among women who were cohabiting (living with a man) rather than married. In almost half of the settings, there was more violence in the past 12 months among women who were separated or divorced, implying in some cases that violence may persist even after separation (WHO, 2005). Studies in Africa and Middle East similarly found marital status to be associated with IPV among women.

Lower educational level in women has been found to be associated with increased risk of IPV. The WHO 
Study found that higher education was associated with less IPV in many settings. In some settings (urban Brazil, Namibia, Peru, Thailand, and the United Republic of Tanzania), the protective effect of education appears to start only when women's education goes beyond secondary school. Research in Europe and Turkey also suggests that education for women has a protective effect, even when controlling for income and age (Alper et al., 2005; Burazeri et al., 2005). In Asia, studies also showed higher level of education to be associated with lower IPV (Campbell, 1999). It may be that women with higher education have a greater range of choice in partners and more ability to choose to marry or not, and are able to negotiate greater autonomy and control of resources within the marriage.

Low socioeconomic status has also been found to be strongly associated with increased risk of IPV (Arias et al., 2005). Women with lower income have been reported to have higher incidents of IPV than those with higher income (Dutton, 1996). Positive association was reported between physical IPV and economic status among rural women in Bangladesh (Koenig et al., 2003). The employment status of women have been found to be associated with their experience of IPV, women who are employed are better empowered and so can resist IPV. Women who were unemployed were found to be at a higher risk of IPV in Israel and Iran (Uster et al., 2007; Olaiz et al., 2006).

Issues relating to IPV have found to be more prevalent in rural settings and urban slums. Rural women tend to adhere more to socio-cultural values that define the gender norms of men and women (e.g. power, gender roles, obligations and responsibilities) and this tends to promote power imbalance between subordinate women and superior men (WHO, 2002). This power imbalance contributes significantly to IPV among rural women (WHO 2005). The 2003 NDHS reported that rural residence was significantly associated with physical IPV (wife beating) (Koenig et al., 2003). A study in Eastern Nigeria by Okemgbo et al. (2002) reported physical violence to be higher in the urban area while sexual violence is higher in the rural areas. In rural Bangladesh, Koenig and colleagues reported that non-Muslim religion such as Christianity was associated with lower risk of IPV (Koenig et al., 2003). Random sample of rural women of reproductive age from the 2003 Nigerian NDHS is suggestive of religious influences on women's attitudes towards IPV and Muslim women were reported to be more likely to tolerate IPV (Koenig et al., 2003).

IPV is a new and evolving area of research particularly in Nigeria and as such there is dearth of literature, especially on community-based studies. The authors did not find any study in military population in Nigeria. So findings from this study will contribute to existing body of knowledge and may serve as a baseline for future studies in military populations. It may also serve as advocacy tool for increased sensitization and response to IPV against women especially in the military population.

Against the background of the above postulations as possible predictors of IPV, this study was aimed at identifying factors associated with IPV among women in civilian and military communities.

\section{Methodology}

The study design was descriptive, comparative, cross-sectional survey with the study population comprising of wives of military men in Lungi military barrack and of civilian men in zone 2, Wuse all in the Federal Capital Territory (FCT), Abuja. Included in the study were female intimate partners (wives) of the head of the households, who were married and living together for at least six months. In the military barrack, female military personnel who were married to civilians and households where both partners were civilians (though living in the barrack) were all excluded from the study. Widows were also excluded in both military and civilian populations.

The minimum sample size formula for comparison of two independent group proportions was used (Abbey et al., 1995)

$$
\text { Minimum sample size } n / \text { group }=\frac{\left(Z_{a}+Z_{B}\right)^{2} \times\left[p_{1}\left(1-p_{1}\right)+p_{2}\left(1-p_{2}\right)\right]}{d^{2}}
$$

where $\mathrm{n}=$ the minimum sample size; $\mathrm{Z}_{\mathrm{a}}=$ Standard normal deviate corresponding to a significance level of $5 \%$ $=1.96 ; \mathrm{Z}_{\mathrm{B}}=$ Standard normal deviate corresponding to statistical power of $80 \%$ for a two tailed test $=0.84 ; \mathrm{p}_{1}$ (proportion 1) $=0.81$ (proportion of women who experienced physical violence in a study in a civilian community in Lagos) (Odujurin, 1999); $\mathrm{p}_{2}$ (proportion 2) $=0.893$ (proportion of women who experienced physical abuse in military population in USA) (Rentz et al., 2006); $d=$ Amount of difference between $\mathrm{p}_{1}$ and $\mathrm{p}_{2}$. 


$$
\begin{gathered}
\mathrm{n} / \text { group }=\frac{(1.96 \times 0.84)^{2} \times[0.81(1-0.81)+(0.893)(1-0.893)]}{(0.082)^{2}}=76.25 \\
\text { Providing for } 70 \% \text { response rate : } \mathrm{n} \text { per group }=\frac{76.25}{0.7}=109
\end{gathered}
$$

However, a sample size of 130 per group was used.

In the selection of study location, Abuja Municipal Area Council (AMAC) was selected purposively out of the six area councils that make up the FCT because it has a concentration of six barracks. Lungi barrack was selected out of the six barracks by simple cluster random sampling using ballot method while Zone 2, Wuse was purposively selected because it appeared to be the closest in features to the barracks in terms of architectural design and ethnic and religious diversity and the fact that majority of the residents are civil servants of various cadre; the area is a distance of about 8 - $10 \mathrm{~km}$ away from the barrack location.

A multi-stage sampling technique was used to select a sample of 130 female respondents from each of the study population (Lungi barrack and Zone 2, Wuse).

For the Lungi barracks, first from available 18 blocks of fats, 7 blocks which contain 266 flats were selected. Systematic sampling method was then used to select 130 flats using a sampling interval of 2 . Households occupying the selected flats constituted the sampling units.

An eligible woman who is the intimate partner of the male head of household in each selected flat was interviewed. Where there were more than one household occupying a flat, only one household selected by simple balloting was taken and in polygamous households, only one female partner selected by balloting was interviewed.

For the civilian community (Zone 2, Wuse), there is a total of 16 streets consisting of 9 long streets with 44 houses per street, and 7 short streets with 23 houses per street. The streets were stratified into short and long streets and 4 streets were selected by simple balloting from each strata, giving a total of 8 streets selected $(4 \times 23$ $=92,44 \times 4=176$, Total is $92+176=268$ houses).

Next a sampling frame was created for each of the selected streets using the house numbering. Where there are blocks of flats, each flat was listed as a house. Total of 268 houses were listed from all the selected streets. Systematic sampling technique was used to select 130 houses from all the selected streets using a sampling interval of 2. Households occupying the selected houses constituted the sampling units. One eligible intimate partner of a household head was then interviewed in each household where there was more than one household occupying a house, only one household was selected by simple balloting and in polygamous households; only one female partner selected by simple balloting was interviewed.

Data collection and analysis: A semi-structured, pre-tested interviewer administered questionnaire was used to collect quantitative data. The questionnaire was adapted from the WHO standardized questionnaire for collection of data on women's health and domestic violence used for the multi-country study on women's' health and life experience. The questionnaire consist of sections on the socio-demographic data of the respondents, the characteristics of respondent's current or most recent partner and forms of intimate partner violence. Two-day training for the research assistants was conducted using the WHO standard training manual for the WHOMSC study (WHO, 2007).

The questionnaire was pre-tested in Sanni Abacha Barracks and Zone 1 Wuse immediately after the training of the research assistants and thereafter corrected to remove areas of ambiguity before the data collection. The data collection took place between May and June 2012. The questionnaires were administered by four trained research assistants and the researcher. Each respondent was interviewed alone using the questionnaire after obtaining an informed consent. Completed questionnaires were reviewed by research assistant and errors and wrong entries corrected before leaving each venue. Completed questionnaires were stored in locked-up bags to further ensure confidentiality.

Data analysis was done using SPSS and Epi-info 2012. Frequencies, proportions and percentages were generated and continuous variables were expressed as means ( \pm standard deviations). Statistical analysis of difference between proportions was carried out using the Pearson Chi-square and Fischer's exact Chi-square test was used wherever the cell content was less than 5 .

Comparison of the association between the different forms of IPV and the respondents socio-demographic and partner characteristics in the two study populations were compared using percentages and Chi square statis- 
tics and p-value assumed at $\leq 0.05$.

Multiple logistic regression analysis was used to predict the outcome of the dependent variable. Predictors of "ever experienced" each of the four variants of violence were determined, "ever experienced" IPV (i.e. controlling behaviour, emotional, physical and sexual violence respectively) being the dependent variable with dichotomous response. The independent variables that were fed in included the respondents' and partners' characteristics which showed statistically significant association in both military and civilian populations. The predictor (independent) variables were entered into the logistic regression model in a single block to control for possible confounders between the predictor variables. The magnitude and direction of the relationship between the variables were expressed as odd's ratio (OR) and significant levels expressed as p-values which was assumed at $p$ $\leq 0.05$.

\section{Result}

In Table 1, the respondents whose intimate partner got involved in a physical fight with another man 14 (93.3\%), and those in relationships where they quarreled often 4 (100.0), were more likely to experience controlling behavior in the civilian population. These two findings are statistically significant ( $p=0.032, p=0.001$ respectively. In the military population, even though the prevalence of controlling behaviour was high among respondents with these risk factors, alcohol 28 (71.8\%), use of hard drugs $8(100.0 \%)$ and male partner involvement in a fight with another man 4 (40\%), these findings are not statistically significant $(p>0.05)$.

Table 2 shows the respondents' characteristics associated with emotional violence in the civilian and military communities. Consumption of alcohol by male partner was found to be significantly associated with the experience of emotional violence among the civilian respondents 14 (51.9\%) and military 36 (92.3\%) respondents, ( $p$ $=0.004)$ and $(p=0.009)$ respectively. Civilian respondents whose partners had been involved in physical fight with another man $33(89.2 \%)$ were more likely to experience emotional violence and this finding is statistically significant $(p=0.000)$ compared to military population where though, there was also higher risk than among the non-consumers of alcohol, the finding is not statistically difference, $p=0.211$. Experience of emotional violence was more in the early stages of relationships among civilian respondents $4(66.7 \%)(p=0.004)$. Respondent in relationships where quarrels were more in both military 11 (73.80\%) and civilian 3 (75.0\%) were at a significantly higher risk of experiencing emotional violence compared to their counterparts with fewer quarrels; $p=$ 0.001 and 0.000 respectively.

In Table 3, the "ever" married 57 (54.3.0\%) were likely to be more at risk of experiencing physical violence among civilians respondent, (this is statistically significant, $p=0.03)$, compared to the "never married" $3(60.0 \%)$ among the military, \{finding not statistically significant, $p>0.05)$ \}. Experience of physical violence was markedly highest among respondents with primary education 4 (100.0\%) among civilians), ( $p=0.032)$; While in the military population, physical violence experience was highest among those with secondary education 34 (43.6\%), followed by those with primary education, though the findings were not statistically significant, $p>0.05$. Respondents of "other" ethnic groups 8 (18.2\%) (apart from the Yoruba, Hausa and Igbo) were significantly most likely to experience physical violence this finding was statistically significant, among both the civilian and military respondents; $p=0.01$. Significantly, higher risk of physical violence was observed among women whose partners consumed alcohol regularly in both civilian 19 (70.4\%) and military 23 (59.0\%) respondents than among those who did not, $p=0.000$. Respondents whose partners took hard drugs were at a markedly higher risk among the military population than those who did not; $(p=0.000)$. Also among civilian respondents, relationships where the partner was ever involved in a physical fight with another man $(p=0.000)$ and where the partners fought often $(p=0.001)$ were at significantly higher risks of physical violence than those who were never involved. Also among the military population, those respondents whose partners consumed alcohol $(p=$ 0.000 ), those who took hard drugs ( $p=0.047$ ), those who had been in relationship for between 3 - 9 years 29 $(55.8 \%)(p=0.036)$ and partners who quarreled more often $(p<0.000)$ appeared to be significantly more at higher risks of experiencing physical violence.

Table 4 shows respondents characteristics associated with sexual violence among civilian and military respondents. Moslem women 8 (38.1\%) among civilians were more likely to experience sexual violence compared to the military where it was the Christians women 15 (17.2\%) that were at a higher risk. This difference is statistically significant $(p=0.016)$. Younger partners were more likely to perpetrate sexual violence in both civilian and military populations; male partners age was inversely proportional to female partner experience of sexual 
Table 1. Respondents/partners socio-demographic characteristics and their experience of controlling behavior.

\begin{tabular}{|c|c|c|c|c|c|c|}
\hline \multirow{2}{*}{$\begin{array}{l}\text { Socio-demographic } \\
\text { characteristics }\end{array}$} & \multicolumn{2}{|c|}{ Civilian $\mathrm{N}=108$} & \multicolumn{4}{|c|}{ Military N = 130} \\
\hline & $\begin{array}{c}\text { Yes } \\
\text { n (\%) }\end{array}$ & $\begin{array}{l}\text { No } \\
\text { n (\%) }\end{array}$ & $\begin{array}{l}\text { Total } \\
\text { n (\%) }\end{array}$ & $\begin{array}{c}\text { Yes } \\
\text { n (\%) }\end{array}$ & $\begin{array}{c}\text { No } \\
\text { n (\%) }\end{array}$ & $\begin{array}{l}\text { Total } \\
\text { n (\%) }\end{array}$ \\
\hline \multicolumn{7}{|l|}{ Ethnicity } \\
\hline Igbo & $11(44.0)$ & $14(56.0)$ & $25(100.0)$ & 10 (76.9) & $3(23.1)$ & $13(100.0)$ \\
\hline Hausa & $9(90.0)$ & $1(10.0)$ & $10(100.0)$ & 19 (52.8) & $17(47.2)$ & $36(100.0)$ \\
\hline Yoruba & $14(48.3)$ & 15 (51.7) & $29(100.0)$ & $13(81.3)$ & $3(18.8)$ & $16(100.0)$ \\
\hline \multirow[t]{2}{*}{ Others } & 35 (79.5) & $9(20.5)$ & $44(100.0)$ & $46(70.8)$ & $19(29.2)$ & $65(100.0)$ \\
\hline & $X^{2}=14.98$ & $p=0.002^{*}$ & & $\mathrm{X}^{2}=5.79$ & $p=0.122$ & \\
\hline \multicolumn{7}{|l|}{ Average monthly income } \\
\hline$<10,000$ & $18(75.0)$ & $6(25.0)$ & $24(100.0)$ & $67(65.7)$ & 35 (34.3) & $102(100)$ \\
\hline $10,000-29,000$ & $10(52.6)$ & $9(41.2)$ & $19(100.0)$ & 17 (13.1) & $7(19.0)$ & $24(100.0)$ \\
\hline $30,000-49,000$ & 1 (33.3.) & $2(66.7)$ & $3(100.0)$ & $3(75.0)$ & $1(25.0)$ & $4(100.0)$ \\
\hline \multirow[t]{2}{*}{$50,000+$} & $12(19.4)$ & $50(80.6)$ & $62(100.0)$ & $0(0.0)$ & $0(0.0)$ & $0(0.0)$ \\
\hline & $X^{2}=24.86$ & $P=0.000^{*}$ & & $X^{2}=3.59$ & $p=0.309$ & \\
\hline \multicolumn{7}{|l|}{ Partner quarrels } \\
\hline Never & $13(41.9)$ & $18(58.1)$ & $31(100.0)$ & $1(16.7)$ & $5(83.3)$ & $6(100.0)$ \\
\hline Rarely & $47(77.0)$ & $14(23)$ & $61(100.0)$ & $12(50.0)$ & $12(50.0)$ & $24(100.0)$ \\
\hline Often & $4(100.0)$ & $0(0.0)$ & $4(100.0)$ & $25(30.1)$ & 58 (69.9) & $83(100.0)$ \\
\hline \multirow[t]{2}{*}{ Very often } & $5(41.7)$ & $7(58.3)$ & $12(100.0)$ & $4(23.5)$ & $13(76.5)$ & $17(100.0)$ \\
\hline & $X^{2}=15.88$ & $P=0.001^{*}$ & & $X^{2}=4.89$ & $p=0.180$ & \\
\hline \multicolumn{7}{|c|}{ Partner use of hard drugs } \\
\hline Yes & $0(0.0)$ & $0(0.0)$ & $0(0.0)$ & $8(100.0)$ & $0(0.0)$ & $8(100.0)$ \\
\hline No & $64(62.1)$ & 39 (37.9) & $103(100.0)$ & $74(64.9)$ & $40(35.1)$ & $114(100.0)$ \\
\hline \multirow[t]{2}{*}{ Don’t know } & $5(100.0)$ & $0(0.0)$ & $5(100.0)$ & $8(80.0)$ & $2(20.0)$ & $10(100.0)$ \\
\hline & $X^{2}=2.96$ & $p=0.085$ & & $X^{2}=4.94$ & $p=0.084$ & \\
\hline \multicolumn{7}{|c|}{ Partner shows aggression to other men } \\
\hline Yes & $14(93.3)$ & $1(6.7)$ & $15(100.0)$ & $4(40.0)$ & $6(60.0)$ & $10(100.0)$ \\
\hline \multirow[t]{2}{*}{ No } & $55(59.1)$ & $38(40.9)$ & $93(100.0)$ & 80 (66.7) & 40 (33.3) & $120(100.0)$ \\
\hline & $X^{2}=6.49$ & $p=0.011$ & & $X^{2}=2.85$ & & $p=0.091$ \\
\hline
\end{tabular}

*denotes statistically significant result.

violence. This association is statistically significant for the military population $(p=0.04)$ but is not in the civilian population $(p=0.44)$. Lower level of education of respondent was more associated with the experience of sexual violence among civilian respondents 4 (100.0\%). Partner's alcohol consumption was likely to be significantly ( $p=0.02)$ associated with sexual violence among the military respondents $14(35.9 \%)$. but in the civilian population, male partner's alcohol consumption did not seem to increase respondents' experience of sexual violence as respondents whose partners were not regular alcohol consumers were more at risk 16 (19.8\%) than those who did $5(18.5 \%)$. This finding is statistically significant $(p=0.00)$. Though no respondent among the civilians admitted to partner using "hard drugs", all those who didn't know if their partner used hard drugs 5 (100.0\%) had higher risk than those who said their partner did not use hard drugs, this difference is statistically significant $(p=0.00)$. Among the respondents whose partners were ever involved in a physical fight with another man 3 (42.9\%) among the civilians and 7 (18.9\%) among military respondents were at a higher risk than those whose partners were never involved in a fight. The difference is statistically significant for civilians $(p=0.02)$ but not for the military $(p=0.06)$.

Table 5 indicates that respondents whose partners consumed alcohol regularly were almost three times at higher risk of experiencing emotional violence compared to those whose partners did not consume alcohol, this difference is statistically significant ( $p=0.004$, OR $=2.8$, CI $=1.39-5.63$ ). Respondents whose partners got involved in physical fight with another man (physical aggression) had three times increased risk of experiencing emotional violence than those whose partners did not. This difference is statistically significant $(p=0.009$, $\mathrm{OR}=3.1$, CI = 3.20 - 19.22). Quarrels in intimate relationship predispose to emotional violence, respondents in 
Table 2. Respondents/partners socio-demographic characteristics and their experience of emotional violence.

\begin{tabular}{|c|c|c|c|c|c|c|}
\hline \multirow{2}{*}{$\begin{array}{l}\text { Socio-demographic } \\
\text { characteristics }\end{array}$} & \multicolumn{2}{|c|}{ Civilian N = 108} & \multirow[b]{2}{*}{$\begin{array}{l}\text { Total } \\
(\%)\end{array}$} & \multicolumn{3}{|c|}{ Military N = 130} \\
\hline & $\begin{array}{c}\text { Yes } \\
\text { n (\%) }\end{array}$ & $\begin{array}{c}\text { No } \\
\text { n (\%) }\end{array}$ & & $\begin{array}{c}\text { Yes } \\
\text { n (\%) }\end{array}$ & $\begin{array}{c}\text { No } \\
\text { n (\%) }\end{array}$ & $\begin{array}{c}\text { Total } \\
(\%)\end{array}$ \\
\hline \multicolumn{7}{|c|}{ Respondents' occupation } \\
\hline Professionals \& Skilled & $19(24.7)$ & $58(75.3)$ & $77(100.0)$ & $11(78.6)$ & $3(21.4)$ & $14(100.0)$ \\
\hline Partly Skilled & $6(46.2)$ & $7(53.8)$ & $13(100.0)$ & $36(65.5)$ & $19(34.5)$ & $55(100.0)$ \\
\hline \multirow[t]{2}{*}{ Unskilled } & $9(50.0)$ & $9(50.0)$ & $18(100.0)$ & $54(88.5)$ & $7(11.5)$ & $61(100.0)$ \\
\hline & $X^{2}=5.81$ & $p=0.054$ & & $X^{2}=8.89$ & $p=0.012$ & \\
\hline \multicolumn{7}{|c|}{ Partner's regular alcohol consumption } \\
\hline Yes & $14(51.9)$ & $13(48.1)$ & $27(100.0)$ & $36(92.3)$ & $3(7.7)$ & $39(100.0)$ \\
\hline \multirow[t]{2}{*}{ No } & $18(22.2)$ & $63(77.8)$ & $81(100.0)$ & $65(71.4)$ & $2628.6)$ & $91(100.0)$ \\
\hline & $\mathrm{X}^{2}=8.45$ & $p=0.004^{*}$ & & $X^{2}=6.81$ & $p=0.009^{*}$ & \\
\hline \multicolumn{7}{|l|}{ Partner's use of hard drug } \\
\hline Yes & $0(0.0)$ & $0(0.0)$ & $0(0.0)$ & $7(87.5)$ & $1(12.5)$ & $8(100.0)$ \\
\hline No & $27(26.2)$ & $76(73.8)$ & $103(100.0)$ & $26(23.2)$ & $86(76.8)$ & $112(100.0)$ \\
\hline \multirow[t]{2}{*}{ Don’t know } & $5(100.0)$ & $0(0.0)$ & $5(100.0)$ & $10(100.0)$ & $0(0.0)$ & $10(100.0)$ \\
\hline & $X^{2}=12.45$ & $p=0.000^{*}$ & $X^{2}=35.86$ & $p=0.000^{* *}$ & & \\
\hline \multicolumn{7}{|l|}{ Partner's physical aggression } \\
\hline Yes & $20(83.3)$ & $4(16.7)$ & $24(100.0)$ & $33(89.2)$ & $4(10.8)$ & $37(100.0)$ \\
\hline \multirow[t]{2}{*}{ No } & $9(10.7)$ & 75 (89.3) & $84(100.0)$ & $35(37.6)$ & $58(62.3)$ & $93(100.0)$ \\
\hline & $X^{2}=49.65$ & $p=0.000^{*}$ & $X^{2}=27.98$ & $p=0.000^{* *}$ & & \\
\hline \multicolumn{7}{|l|}{ Duration of relationship $^{* *}$} \\
\hline$\leq 2$ years & $4(66.7)$ & $2(33.3)$ & $6(100.0)$ & $9(69.2)$ & $4(30.7)$ & $13(100.0)$ \\
\hline $3-9$ years & $16(51.6)$ & $15(48.4)$ & $31(100.0)$ & $46(74.2)$ & $16(25.8)$ & $62(100.0)$ \\
\hline \multirow[t]{2}{*}{$\geq 10$ years } & $15(21.1)$ & 56 (78.9) & $71(100.0)$ & $46(83.6)$ & $9(16.4)$ & $55(100.0)$ \\
\hline & $X^{2}=12.56$ & & $p=0.002^{*}$ & $X^{2}=2.10$ & $p=0.351$ & \\
\hline \multicolumn{7}{|l|}{ Frequency of quarrel $^{* *}$} \\
\hline Never & $6(19.4)$ & $25(80.6)$ & $31(100.0)$ & $0(0.0)$ & $6(100.0)$ & $6(100.0)$ \\
\hline Rarely & $14(23.0)$ & $47(77.0)$ & $61(100.0)$ & $24(26.1)$ & 68 (73.9) & $92(100.0)$ \\
\hline Often & $3(75.0)$ & $1(25.0)$ & $4(100.0)$ & $11(73.3)$ & $4(26.7)$ & 15 (100.0) \\
\hline \multirow[t]{2}{*}{ Very often } & 8 (66.7) & $4(33.3)$ & $12(100.0)$ & 13 (76.5) & $4(23.5)$ & $17(100.0)$ \\
\hline & $X^{2}=14.95$ & $p=0.002^{*}$ & $X^{2}=28.10$ & $p=0.000^{*}$ & & \\
\hline
\end{tabular}

* statistically significant, ${ }^{* *}$ Fischer's exact p-value.

relationships where they quarreled very often had almost 30 times higher risk compared to those that rarely quarreled $(p=0.002$, OR $=29.7,95 \% \mathrm{CI}=3.5-252.4)$. The table also shows the factors associated with physical violence. Respondents of Yoruba ethnic group had 4 times more risk of experiencing physical violence, this difference is statistically significant $(p=0.043$, OR $=4.31,95 \% \mathrm{CI}=1.04-17.77)$. Also respondents whose marriages were more than two years but less than 10 years had 4 times significantly higher risk of experiencing physical violence than their younger counterparts; ( $p=0.001$, OR $=4.02,95 \% \mathrm{CI}=1.7-9.3$ ).

Table 6 shows the logistic regression for predictors of sexual violence. Moslem women were found to at a higher risk ( $p=0.000, \mathrm{OR}=5.23, \mathrm{CI}=3.02-13.5)$ of experiencing sexual violence compared to respondents of other religion. Respondents who were unskilled professionally were over five times at a markedly higher risk of experiencing sexual violence from their intimate partners compared to the professionals; $(p=0.024$, OR $=5.52$, $\mathrm{CI}=4.26$ - 24.27). Similarly, alcohol consumption by respondent's partner was found to be a significant predictor of sexual violence among the respondents, $(p=0.012)$.

\section{Discussion}

Several factors have been found to be associated with experiencing IPV by women. Controlling behaviour 
Table 3. Respondents/partners socio-demographic characteristics and their experience of physical violence.

\begin{tabular}{|c|c|c|c|c|c|c|}
\hline \multirow{2}{*}{$\begin{array}{l}\text { Socio-demographic } \\
\text { characteristics }\end{array}$} & \multicolumn{6}{|c|}{ Civilian N = 108} \\
\hline & Yes n (\%) & No n (\%) & Total (\%) & Yes n (\%) & No n (\%) & Total (\%) \\
\hline \multicolumn{7}{|c|}{ Respondent's educational level } \\
\hline None & $2(66.7)$ & $1(33.3)$ & $3(100.0)$ & $0(0.0)$ & $5(100.0)$ & $5(100.0)$ \\
\hline Primary & $4(100.0)$ & $0(0.0)$ & $4(100.0)$ & $6(35.3)$ & $11(64.7)$ & $17(100.0)$ \\
\hline Secondary & $3(8.8)$ & $31(91.2)$ & $34(100.0)$ & $34(43.6)$ & $44(56.4)$ & $78(100.0)$ \\
\hline \multirow[t]{2}{*}{ Tertiary } & $9(13.4)$ & $58(86.6)$ & $67(100.0)$ & $7(23.3)$ & $23(76.7)$ & $30(100.0)$ \\
\hline & $X^{2}=27.41$ & & $p=0.000^{*}$ & $X^{2}=6.84$ & $p=0.077$ & \\
\hline \multicolumn{7}{|c|}{ Respondent's ethnicity } \\
\hline Igbo & $2(8.0)$ & $23(92.0)$ & $25(100.0)$ & $5(38.5)$ & $8(61.5)$ & $13(100.0)$ \\
\hline Hausa & $0(0.0)$ & $10(100.0$ & $10(100.0)$ & $5(3.8)$ & $31(23.8)$ & $36(100.0)$ \\
\hline Yoruba & $4(16.0)$ & $25(84.0)$ & $29(100.0)$ & $9(6.9)$ & $7(5.4)$ & $16(100.0)$ \\
\hline \multirow[t]{2}{*}{ Others } & $8(18.2)$ & 36 (81.8) & $44(100.0)$ & $28(21.5)$ & 37 (28.5) & $65(100.0)$ \\
\hline & $X^{2}=3.12$ & & $p=0.37$ & $X^{2}=11.91$ & & $p=0.010^{*}$ \\
\hline \multicolumn{7}{|c|}{ Partner's use of hard drug } \\
\hline Yes & $0(0.0)$ & $0(0.0)$ & $0(0.0)$ & $5(62.5)$ & $3(37.5)$ & $8(100.0)$ \\
\hline No & $10(9.7)$ & $93(90.3)$ & 103(100.0) & $37(33.0)$ & $75(67.0)$ & $112(100.0)$ \\
\hline \multirow[t]{2}{*}{ Don’t know } & $4(80.0)$ & $1(20.0)$ & $5(100.0)$ & $7(70.0)$ & $3(30.0)$ & $10(100.0)$ \\
\hline & $X^{2}=20.88$ & $p=0.000^{*}$ & & $X^{2}=7.57$ & $p=0.022^{*}$ & \\
\hline \multicolumn{7}{|c|}{ Partner ever involved in physical fight } \\
\hline Yes & $10(41.7)$ & $14(58.3)$ & $24(100.0)$ & $10(27.0)$ & $27(77.0)$ & $37(100.0)$ \\
\hline \multirow[t]{2}{*}{ No } & $7(13.1)$ & 77 (86.9) & $84(100.0)$ & $13(14.0)$ & $80(86.0)$ & $93(100.0)$ \\
\hline & $X^{2}=15.49$ & $p=0.00^{*}$ & & $X^{2}=3.07$ & $p=0.08$ & \\
\hline \multicolumn{7}{|c|}{ Duration of relationship with partner } \\
\hline$\leq 2$ & $0(0.0)$ & $6(100.0)$ & $6(100.0)$ & $2(15.4)$ & $11(84.6)$ & $13(100.0)$ \\
\hline $3-9$ & $7(22.6)$ & $24(77.4)$ & $31(100.0)$ & $29(55.8)$ & $33(53.2)$ & $62(100.0)$ \\
\hline \multirow[t]{2}{*}{$\geq 10$} & 7 (9.9) & $64(90.1)$ & $71(100.0)$ & $16(29.1)$ & 39 (70.9) & $55(100.0)$ \\
\hline & $X^{2}=4.04$ & $p=0.132$ & & $X^{2}=6.65$ & $p=0.04^{*}$ & \\
\hline \multicolumn{7}{|l|}{ Frequency of quarrel } \\
\hline Never & $3(9.7)$ & 28 (90.3) & $31(100.0)$ & $2(33.3)$ & $4(66.7)$ & $6(100.0)$ \\
\hline Rarely & $8(13.1)$ & 53 (86.9) & $61(100.0)$ & $34(37.0)$ & $54(63.0)$ & $88(100.0)$ \\
\hline Often & $3(75.0)$ & $1(25.0)$ & $4(100.0)$ & $10(66.7)$ & $5(33.3)$ & $15(100.0)$ \\
\hline \multirow[t]{2}{*}{ Very often } & $12(100.0)$ & $0(0.0)$ & $12(100.0)$ & $11(64.7)$ & $6(35.3)$ & $17(100.0)$ \\
\hline & $X^{2}=4.04$ & $p=0.132$ & & $\mathrm{X}^{2}=6.65$ & $p=0.04^{*}$ & \\
\hline \multicolumn{7}{|c|}{ Number of children alive } \\
\hline None & $0(0.0)$ & $8(100.0)$ & $8(100.0)$ & $3(33.3)$ & $6(66.7)$ & $9(100.0)$ \\
\hline $1-2$ & $6(14.0)$ & 37 (86.0) & $43(100.0)$ & $17(44.0)$ & $33(66.0)$ & $50(100.0)$ \\
\hline $3-4$ & $7(20.0)$ & $38(80.0)$ & $45(100.0)$ & 19 (31.7) & $41(68.3)$ & $60(100.0)$ \\
\hline \multirow[t]{2}{*}{$\geq 5$} & $1(8.3)$ & $11(91.7)$ & $12(100.0)$ & $8(72.7)$ & $3(27.3)$ & $11(100.0)$ \\
\hline & $\mathrm{X}^{2}=1.725$ & $p=0.63$ & & $X^{2}=7.03$ & $p=0.07$ & \\
\hline
\end{tabular}

*denotes statistically significant result.

among civilian population was found to be associated with being of Hausa ethnic group, being partially skilled professionally, earning low income and quarrelling often in relationship. It is not surprising that this study found Hausa women to be at a greater risk of experiencing controlling behaviour than other ethnic groups. It is a well known fact that women of certain religious inclination from the Northern part of the country, as part of their religious belief experience more controlling behaviour from their male partner than those from other parts. The religious background may also be a plausible explanation for the Yorubas since some of them are of similar religion. Frequent quarrels in a relationship may be as a result of the man trying to stamp his authority and control 
Table 4. Respondents/partners socio-demographic characteristics and their experience of sexual violence.

\begin{tabular}{|c|c|c|c|c|c|c|}
\hline \multirow{2}{*}{$\begin{array}{l}\text { Socio-demographic } \\
\text { characteristics }\end{array}$} & \multicolumn{2}{|c|}{ Civilian N = 108} & \multicolumn{4}{|c|}{ Military N = 130} \\
\hline & $\begin{array}{c}\text { Yes } \\
\text { n (\%) }\end{array}$ & $\begin{array}{c}\text { No } \\
\text { n (\%) }\end{array}$ & $\begin{array}{l}\text { Total } \\
\text { n(\%) }\end{array}$ & $\begin{array}{c}\text { Yes } \\
\text { n (\%) }\end{array}$ & $\begin{array}{c}\text { No } \\
\text { n (\%) }\end{array}$ & $\begin{array}{l}\text { Total } \\
\text { n (\%) }\end{array}$ \\
\hline \multicolumn{7}{|c|}{ Respondent's level of education } \\
\hline None & $0(0.0)$ & $3(100.0)$ & $3(100.0)$ & $1(20.0)$ & $4(80.0)$ & $5(100.0)$ \\
\hline Primary & $1(25.0)$ & $3(75.0)$ & $4(100.0)$ & $2(11.8)$ & $15(88.2)$ & $17(100.0)$ \\
\hline Secondary & $0(0.0)$ & $34(100.0)$ & $34(100.0)$ & $16(20.5)$ & $62(79.5)$ & $78(100.0)$ \\
\hline \multirow[t]{2}{*}{ Tertiary } & $8(11.9)$ & $59(88.1)$ & $67(100.0)$ & $3(10.0)$ & $27(90.0)$ & $30(100.0)$ \\
\hline & $X^{2}=5.96$ & $p=0.113$ & & $X^{2}=2.09$ & $p=0.55$ & \\
\hline \multicolumn{7}{|l|}{ Respondent's religion } \\
\hline Christianity & $13(14.9)$ & $74(85.1)$ & $87(100.0)$ & $15(17.2)$ & $72(82.8)$ & $87(100.0)$ \\
\hline Islam & $8(38.1)$ & 13 (61.9) & $21(100.0)$ & $6(14.3)$ & 36 (85.7) & $42(100.0)$ \\
\hline \multirow[t]{2}{*}{ Traditional } & $0(0.0)$ & $0(0.0)$ & $0(0.0)$ & $1(100.0)$ & $0(0.0)$ & $1(100.0)$ \\
\hline & $X^{2}=5.79$ & $p=0.02^{*}$ & & $X^{2}=5.12$ & $p=0.077$ & \\
\hline \multicolumn{7}{|l|}{ Respondent's ethnicity } \\
\hline Igbo & $9(36.0)$ & $16(64.0)$ & $25(100.0)$ & $0(0.0)$ & $13(100.0)$ & $13(100.0)$ \\
\hline Hausa & $6(60.0)$ & $4(40.0)$ & $10(100.0)$ & $4(11.1)$ & 32 (88.9) & $36(100.0)$ \\
\hline Yoruba & $4(13.8)$ & $25(86.2)$ & $29(100.0)$ & $4(25.0)$ & $12(75.0)$ & $16(100.0)$ \\
\hline \multirow[t]{2}{*}{ Others } & $2(4.5)$ & $42(95.5)$ & $44(100.0)$ & $14(21.5)$ & $51(78.5)$ & $65(100.0)$ \\
\hline & $X^{2}=21.70$ & $p=0.00^{*}$ & & $X^{2}=5.24$ & $p=0.155$ & \\
\hline \multicolumn{7}{|l|}{ Respondent's occupation } \\
\hline Professional \& Skilled & $17(22.1)$ & 60 (77.9) & $77(100.0)$ & $2(14.3)$ & $12(85.7)$ & $14(100.0)$ \\
\hline Partly Skilled & $2(15.5)$ & $11(84.6)$ & $13(100.0)$ & $2(4.2)$ & 46 (95.8) & $48(100.0)$ \\
\hline \multirow[t]{2}{*}{ Unskilled } & $2(12.5)$ & $16(87.5)$ & $18(100.0)$ & $18(26.5)$ & $50(72.5)$ & $68(100.0)$ \\
\hline & $X^{2}=1.28$ & $p=0.528$ & & $X^{2}=10.03$ & $p=0.06$ & \\
\hline \multicolumn{7}{|c|}{ Partner's level of education } \\
\hline None & $1(33.3)$ & $2(66.7)$ & $3(100.0)$ & $0(0.0)$ & $0(0.0)$ & $0(0.0)$ \\
\hline Primary & $4(100.0)$ & $0(0.0)$ & $4(100.0)$ & $0(0.0)$ & $0(0.0)$ & $0(0.0)$ \\
\hline Secondary & $8(23.6)$ & $26(76.4)$ & $34(100.0)$ & $23(23.0)$ & $77(77.0)$ & $100(100.0)$ \\
\hline \multirow[t]{2}{*}{ Tertiary } & $12(17.9)$ & $55(82.1)$ & $67(100.0)$ & $3(10.0)$ & $27(90.0)$ & $30(100.0)$ \\
\hline & $X^{2}=14.49$ & $p=0.002$ & $X^{2}=2.40$ & & $p=0.31$ & \\
\hline \multicolumn{7}{|c|}{ Partner consumed alcohol regularly } \\
\hline Yes & $5(18.5)$ & 22(81.5) & $27(100.0)$ & $14(35.9)$ & $25(64.1)$ & $39(100.0)$ \\
\hline \multirow[t]{2}{*}{ No } & $16(19.8)$ & $65(80.2)$ & $81(100.0)$ & $8(8.8)$ & $83(91.2)$ & $91(100.0)$ \\
\hline & $X^{2}=0.02$ & $p=0.89$ & & $X^{2}=14.27$ & $p=0.00^{*}$ & \\
\hline \multicolumn{7}{|l|}{ Partner use of hard drugs } \\
\hline Yes & $0(0.0)$ & $0(0.0)$ & $0 \quad(0.0)$ & $4(50.0)$ & $4(50.0)$ & $8(100.0)$ \\
\hline No & $16(15.5)$ & $87(84.5)$ & 103(100.0) & $16(14.0)$ & $98(86.0)$ & $114(100.0)$ \\
\hline \multirow[t]{2}{*}{ Don’t know } & $5(100.0)$ & $0(0.0)$ & $5(100.0)$ & $4(40.0)$ & $6(60.0)$ & $10(100.0)$ \\
\hline & $X^{2}=21.72$ & $p=0.00^{*}$ & & $X^{2}=9.96$ & $p=0.006$ & \\
\hline \multicolumn{7}{|c|}{ Frequency of quarrels with partner } \\
\hline Never & $4(12.9)$ & $27(87.1)$ & $31(100.0)$ & $3(11.5)$ & $23(88.5)$ & $6(100.0)$ \\
\hline Rarely & $10(16.4)$ & 51(83.6) & $61(100.0)$ & $5(33.3)$ & $10(66.7)$ & $92(100.0)$ \\
\hline Often & $4(100)$ & $0(0.0)$ & $4(100.0)$ & $(0.0)$ & $0(0.0)$ & $15(100.0)$ \\
\hline \multirow[t]{2}{*}{ Very often } & $3(25.0)$ & $9(75.0)$ & $12(100.0)$ & $0(0.0)$ & $6(100.0)$ & $17(100.0)$ \\
\hline & $X^{2}=18.02$ & $p=0.00^{*}$ & & $X^{2}=4.63$ & $p=0.20$ & \\
\hline
\end{tabular}

*denotes statistically significant result.

over his intimate partner and the later in turn putting up some measure of resistance. 
Table 5. Logistic regression model for predictors of controlling behavior, emotional and physical violence.

\begin{tabular}{|c|c|c|c|}
\hline & $p$ & OR & $95 \% \mathrm{CI}$ \\
\hline \multicolumn{4}{|c|}{ Controlling behaviour } \\
\hline \multicolumn{4}{|c|}{ Frequency of quarrel } \\
\hline Very often & $0.002^{*}$ & 29.71 & $3.5-252.35$ \\
\hline Often & $0.005^{*}$ & 9.73 & $1.97-48.15$ \\
\hline Rarely & 0.007 & 1.00 & $1.76-3.11$ \\
\hline \multicolumn{4}{|c|}{ Emotional violence partner's alcohol consumption } \\
\hline Yes & $0.004^{*}$ & 2.8 & $1.39-5.63$ \\
\hline No & 0.000 & 1.00 & $0.987-1.02$ \\
\hline \multicolumn{4}{|c|}{ Physical aggression } \\
\hline Yes & $0.009^{*}$ & 3.1 & $3.20-19.22$ \\
\hline No & 0.0 .02 & 1.00 & $0.947-2.41$ \\
\hline \multicolumn{4}{|c|}{ Duration of relationship } \\
\hline$\leq 2$ years & 0.128 & 2.53 & $0.77-8.37$ \\
\hline $\begin{array}{l}3-9 \text { years } \\
>10 \text { years }\end{array}$ & $0.011^{*}$ & 2.27 & $1.20-4.29$ \\
\hline \multicolumn{4}{|c|}{ Frequency of quarrel } \\
\hline Very often & $0.002^{*}$ & 29.71 & $3.5-252.35$ \\
\hline Often & $0.005^{*}$ & 9.73 & $1.97-48.15$ \\
\hline Rarely & 0.007 & 1.00 & $1.76-3.11$ \\
\hline \multicolumn{4}{|c|}{ Physical violence } \\
\hline \multicolumn{4}{|l|}{ Ethnicity Hausa } \\
\hline Igbo & 0.584 & 1.55 & $0.32-7.39$ \\
\hline Yoruba & $0.043^{*}$ & 4.31 & $1.04-17.77$ \\
\hline Others & 0.069 & 3.22 & $0.91-11.34$ \\
\hline \multicolumn{4}{|c|}{ Partner alcohol consumption } \\
\hline Yes & $0.000^{*}$ & 5.98 & $2.56-13.98$ \\
\hline No & $0.046^{*}$ & 1.00 & $1.02-2.54$ \\
\hline \multicolumn{4}{|c|}{ Length of relationship } \\
\hline$\leq 2$ years & 0.998 & 1.00 & $0.67-4.83$ \\
\hline $\begin{array}{l}3 \text { - } 9 \text { years } \\
\geq 10 \text { years }\end{array}$ & $\begin{array}{l}0.001^{*} \\
0.721\end{array}$ & $\begin{array}{l}4.02 \\
0.73\end{array}$ & $\begin{array}{c}1.74-9.28 \\
0.0 .54-4.22\end{array}$ \\
\hline \multicolumn{4}{|c|}{ Partner hard drug use } \\
\hline $\begin{array}{c}\text { Yes } \\
\text { No } \\
\text { Constant }\end{array}$ & $\begin{array}{c}0.033^{*} \\
0.322\end{array}$ & $\begin{array}{l}2.86 \\
1.00 \\
\mathbf{1 . 0 0}\end{array}$ & $\begin{array}{l}1.07-4.30 \\
1.20-5.44\end{array}$ \\
\hline
\end{tabular}

*denotes statistically significant result.

In this study, emotional violence among the civilian respondents was found to be associated with partner alcohol consumption, involvement in a physical fight with another man, being younger in relationship and quarreling often while in the military population, alcohol consumption and quarreling often were related. In the logistic regression, alcohol consumption and frequent quarrels in a relationship were found to be strong predictors of experiencing emotional violence. Being younger in relationship invariably means younger age group; younger people tend to be less tolerant, less patient and less enduring. When provoked they are more likely to react more rashly than older people. Consumption of alcohol and/or psychoactive drugs tend to remove inhibition and make people lose control over their emotions and so are more likely to perpetrate violence even towards their intimate partner (Family Violence Prevention Fund, 2010). Alcohol consumption is almost a daily occurrence in military circles as the only social life the soldiers have is in the "Mess" and for the lower ranks in the "Mammy" market which exists in every barrack and here even locally brewed alcoholic drinks are sold and consumed and psychoactive drugs cannot be ruled out. Other researchers have documented similar findings. In the WHOMSC (WHO, 2005) study, younger, ever-partnered women were found to be at higher risk, the study also demonstrated 
Table 6. Logistic regression model for predictors of sexual violence.

\begin{tabular}{|c|c|c|c|}
\hline & $p$ & OR & $95 \% \mathrm{CI}$ \\
\hline \multicolumn{4}{|l|}{ Respondent' religion } \\
\hline Christians & 0.402 & 1.46 & $0.60-3.55$ \\
\hline $\begin{array}{l}\text { Islam } \\
\text { Others }\end{array}$ & $\begin{array}{l}0.000^{*} \\
0.002^{*}\end{array}$ & $\begin{array}{l}5.23 \\
1.00\end{array}$ & $\begin{array}{c}3.02-13.15 \\
0.99-4.33\end{array}$ \\
\hline \multicolumn{4}{|l|}{ Respondent's occupation } \\
\hline Unskilled & $0.024^{*}$ & 5.52 & $4.26-24.27$ \\
\hline $\begin{array}{c}\text { Partially skilled } \\
\text { Professional/skilled } \\
\text { Partner's age group }\end{array}$ & $\begin{array}{l}0.050^{*} \\
0.052\end{array}$ & $\begin{array}{l}3.89 \\
1.00\end{array}$ & $\begin{array}{c}1.00-15.28 \\
0.97-8.76\end{array}$ \\
\hline $\begin{array}{l}25-34 \\
35-44\end{array}$ & $\begin{array}{l}0.060 \\
0.420\end{array}$ & $\begin{array}{l}2.05 \\
1.47\end{array}$ & $\begin{array}{l}1.22-5.17 \\
0.98-3.87\end{array}$ \\
\hline $45+$ & 0.940 & 0.84 & $0.75-2.22$ \\
\hline \multicolumn{4}{|c|}{ Partner's use of hard drug } \\
\hline No & 0.361 & 1.00 & $1.10-2.32$ \\
\hline Yes & 0.819 & 2.35 & $0.11-17.23$ \\
\hline \multicolumn{4}{|l|}{ Alcohol consumption } \\
\hline No & $0.032^{*}$ & 1.00 & $0.97-2.09$ \\
\hline Yes & $0.012^{*}$ & 1.99 & $0.82-4.80$ \\
\hline \multicolumn{4}{|l|}{ Physical fighting } \\
\hline No & 0.072 & 1.00 & $0.968-3.13$ \\
\hline Yes & 0.207 & 3.24 & $2.02-7.22$ \\
\hline \multicolumn{4}{|l|}{ Frequency of quarrel } \\
\hline Very often & 0.314 & 2.49 & $0.42-14.73$ \\
\hline Often & 0.295 & 1.43 & $0.09-2.10$ \\
\hline Rarely & 0.746 & 0.79 & $0.19-3.26$ \\
\hline Constant & 1.00 & & \\
\hline
\end{tabular}

*denotes statistically significant result.

that violence tend to start early in marriage. Studies in America (CDC, 2012; Vest et al., 2003). Canada (Thurston et al., 2006) Mexico (Olaiz et al., 2006) and Sri-Lanka (Subramaniam et al., 2001) corroborated this finding. Both alcohol and hard drugs have been documented to reduce inhibition (Jewkes et al., 2002).

In this study, physical violence was found to be associated with low educational level, partner consuming alcohol, and involvement in physical fight with another man, quarreling often among the civilian population. For the military population, being of Yoruba tribe, partner consuming alcohol and use of psychoactive drugs, longer duration of relationship and quarreling often are the associated factors. This finding is similar to that by other researchers who reported strong association between alcohol and psychoactive drugs with physical violence (Subramaniam et al., 2001; Jewkes et al., 2002). Also in some military studies ethnicity was found to be an associated factor in the risk for physical violence (Rentz et al., 2006; Rentz et al., 2011).

Regarding sexual violence, this study found the following factors to be associated with sexual violence, being a Moslem, male partner involvement in physical fight with another man, quarreling often among civilian respondents and being unskilled, partner's younger age and consumption of alcohol in the military population. An aggressive man may not be able to draw a line where his aggression stops and may extend this same aggression in satisfying his sexual urge at will. Women who are unskilled also earn low income, have low self-esteem and self-worth and as such are at the mercy of their partners whom they are economically dependent upon. Being more educated and economically empowered are factors that have been found to be more associated with sexual violence by an intimate partner, (WHO, 2002) the findings of this study is contrary to this. However it corroborates findings in Mexico (Subramaniam et al., 2001) in which prevalence of IPV was higher among women with lower educational level. WHOMCS (WHO, 2005) study reported that younger ever-partnered especially those in the age range of 15 - 19 years were at a higher risk of experiencing physical and sexual violence. Logistic regression showed only being unskilled occupationally in both military populations to be a predictor of experiencing sexual violence. 


\section{Conclusion}

Both military and civilian respondents experienced similar risks for IPV and these risk factors appeared to cut across the various forms of IPV. The major ones include: low socioeconomic status of women, partner alcohol consumption and use of hard drugs. Other identified factors include younger age of both the respondent and partner, shorter duration of relationships and quarreling very often in relationships.

It is therefore recommended that at the family level, there should be value re-orientation and discouragement of family norms that promote negative unbalanced patriarchy through health education. Both the male and female child should be given equal opportunities for self-actualization. Practices such as male preference superior treatment of male child in the family should be encouraged.

Communities should be sensitized through mass media and religious leaders to the fact that IPV is a public health problem and of the urgent need to start addressing the societal norms that drive it, such as our patriarchal systems of socialization and cultural practices which favour the interests of men above those of women. Reaching out to men's groups through advocacy and education to discourage some habits (alcohol, hard drugs, aggression, etc.), attitudes and beliefs that promote abusive behaviours, "the message should be that the abuser of today is a father of the abused tomorrow and sensible and responsible men will not stand their daughters being abused”. At the community level, individuals and families should be encouraged and sensitized to the public health importance of eliminating IPV and how this can impact positively on women, children and development. NGOs working in this area should also be encouraged on short term to establish temporary shelters where feasible, provide empowerment programmes and assist victim in seeking legal redress where necessary. The religious communities, since they are important source where IPV victims seek support should be sensitized to be more proactive in preaching against IPV and IPV “drivers” as well as stigmatize abusers as a deterrent. They should also assist in providing support for victims. People in position of authority/opinion leaders should speak-out and champion positive behavioural change.

At all levels of their development, young people should be taught to have respect for human life and rights to enable them build from violent-free families to violent-free society.

\section{Limitations and Future Research Trends}

The security problem ("Boko Haram scares") in Abuja was a challenge both in the barrack and the civilian communities so much so that it was almost impossible to gain access into people's homes to conduct the interviews. To overcome this, health workers who were involved in the house to house distribution of insecticide treated mosquito nets/polio immunization in FCT were used to facilitate easy access into homes in the study communities.

In future, long-term interventional studies may be designed to ascertain the effect of family re-orientation measures on the prevalence of the various types of IPV in Nigerian families.

\section{References}

Abbey, A., Ross, L. T., \& McDuffie, D. (1995). Alcohol’s Role in Sexual Assault. In R. R. Watson (Ed.), Drug and Alcohol Reviews: Additive Behaviours in Women (pp. 2-25). Totowa, NJ: Human Press.

Alper, Z., Ergin, N., Selimogu, K., \& Bilgel, N. (2005). Domestic Violence: A Study among a Group of Turkish Women. European Journal of general Practice, 11, 48-54. http://dx.doi.org/10.3109/13814780509178237

Arias, I., \& Corso, P. (2005). Average Cost per Person Victimized by an Intimate Partner of the Opposite Gender: A Comparison of Men and Women. Violence and Victims, 20, 379-391. http://dx.doi.org/10.1891/0886-6708.20.4.379

Bradley, C. S. (1985). Attitudes and Practices Relating to Marital Violence among the Tolai of East New Britain. In S. Toft (Ed.), Domestic Violence in Papua New Guinea (PNG) (pp. 32-71). Boroko: PNG Law Reform Commission.

Burazeri, G., Roshi, E., Jewkes, R., Jordan, S., Bjegovic, V., \& Laaser, U. (2005). Factors Associated with Spousal Physical Violence in Albania: Cross Sectional Study. BMJ, 331, 197-201. http://dx.doi.org/10.1136/bmj.331.7510.197

Campbell, J. (1999). Voices of Strength and Resistance: A Contextual and Longitudinal Analysis of Women's Response to Battering. Journal of Interpersonal Violence, 13, 743-762. http://dx.doi.org/10.1177/088626098013006005

Centre for Disease Control and Prevention (CDC) (2012). National Centre for Injury Prevention and Control. Intimate Partner Violence Facts Sheet. http://www.cdc.gov/ncipc/dvp/ipv_factsheet.pdf

Dutton, M. A. (1996). Battered Women’s Strategic Response to Violence: The Role of Context. In J. L. Edelson, \& S. C. Ei- 
sikovits (Eds.), Future Interventions with Battered Women and Their Families (pp. 105-124). London: Sage.

Family Violence Prevention Fund (2010). Facts Sheet: Intimate Partner Violence and Healthy People, End Abuse.

Hindin, M. J., \& Adair, L. S. (2002). Who’s at Risk? Factors Associated with Intimate Partner Violence in the Philippines. Social Science \& Medicine, 55, 1385-1399. http://dx.doi.org/10.1016/S0277-9536(01)00273-8

Ilika, A. L., Okonkwo, P. I., \& Adogu, P. (2002). Intimate Partner Violence among Women of Childbearing Age in a Primary Health Care Centre in Eastern Nigeria. African Journal of Reproductive Health, 6, 53-58. http://dx.doi.org/10.2307/3583257

Jewkes, R., Levin, J., \& Penn-Kekana, L. (2002). Risk Factors for Domestic Violence: Findings from a South African CrossSectional Study. Social Science \& Medicine, 55, 1603-1617. http://dx.doi.org/10.1016/S0277-9536(01)00294-5

Koenig, M. A., Ahmed, S., Hossain, M. B., \& Khorshed Alam Mozumder, A. B. M. (2003). Women’s Status and Domestic Violence in Rural Bangladesh: Individual and Community Level Effects. Demography, 40, 269-288. http://dx.doi.org/10.1353/dem.2003.0014

Koenig, M. A., Lutalo, T., Zhao, F., Nalugoda, F., Wabwire-Mangen, F., Kiwanuka, N. et al. (2003). Domestic Violence in Rural Uganda: Evidence from a Community Based Study. Bulletin of the World Health Organization, 81, 50-60.

Maziak, W., \& Asfar, T. (2003) Physical Abuse in Low Income Women in Aleppo, Syria. Healthcare for Women International, 24, 313-326. http://dx.doi.org/10.1080/07399330390191689

Odujurin, O. (1999). Wife Battering in Nigeria. International Journal of Gynaecology and Obstetrics, 41, 159-164. http://dx.doi.org/10.1016/0020-7292(93)90699-W

Okemgbo, C. N., Omide, A. K., \& Odimegwu, C. O. (2002). Prevalence, Patterns and Correlates of Domestic Violence Inselected Igbo Communities of Imo State, Nigeria. African Journal of Reproductive Health, 6, 101-114. http://dx.doi.org/10.2307/3583136

Olaiz, G., Rojas, R., Valdez, R., Franco, A., \& Palma, O. (2006). Gender Violence Prevalence in Female Users of Health Services in Mexico. Salud Pública de México, 48, S232-S238. http://dx.doi.org/10.1590/S0036-36342006000800003

Rentz, E. D., Martin, S. L., Gibbs, D. A., Clinton-Sherrod, M., Hardison, J., \& Marshall, S. W. (2006). Family Violence in the Military: A Review of the Literature. Trauma, Violence \& Abuse, 7, 93-108. http://dx.doi.org/10.1177/1524838005285916

Rentz, E. D., Martin, S. L., Gibbs, D. A., Clinton-Sherrod, M., Hardson, J., \& Marshall, S. W. (2011). Family Violence in the Military: A Review of the Literature. Annals of the American Academy of Political and Social Science, 638, 163-183.

Schuler, S. R., Hashemi, S. M., Riley, A. P., \& Akhter, S. (1996). Credit Programs, Patriarchy and Men’s Violence. Center for Health and Gender Equity (CHANGE) (Ed.), Proceedings of the 3rd Annual Meeting of the International Research Network on Violence against Women, 11, 36-41.

Subramaniam, P., \& Sivayogan, S. (2001). The Prevalence and Pattern of Wife Beating in the Trincomalee District in Eastern Sri Lanka. The Southeast Asian Journal of Tropical Medicine and Public Health, 32, 186-195.

Thaler, K. (2011) Drivers of Male Perpetration of Family and Intimate Partner Violence in Cape Town. Centre for Social Science Research (CSSR) Working Paper, No. 289.

Thurston, W. E., Patten, S., \& Lagendyk, L. E. (2006). Prevalence of Violence against Women Reported in a Rural Health Region. Canadian Journal of Rural Medicine, 11, 259-267.

Usta, J., Farver, J. A., \& Pashayan, N. (2007). Domestic Violence: The Lebanese Experience. Public Health, 121, $208-220$. http://dx.doi.org/10.1016/j.puhe.2006.09.014

Vest, J. R., Catlin, T. K., Chen, J. J., \& Brownson, R. C. (2002). Multistate Analysis of Factors Associated with Intimate Partner Violence. The American Journal of Medicine, 22, 156-164.

Vest, J. R., Catlin, T. K., Chen, J. J., \& Brownson, R. C. (2003). Factors Associated with Intimate Partner Violence. The American Journal of Medicine, 23, 56-64.

World Health Organization (1997). A Priority Health Issue. Geneva: WHO/FRH/WHD/97, 8.

World Health Organization (2002). World Report on Violence and Health. 114-146.

World Health Organization (2005). WHO Multi-Country Study on Women’s Health and Domestic Violence against Women: Initial Results on Prevalence, Health Outcomes and Women’s Responses. Geneva: WHO.

World Health Organization (2007). Revised Interviewer Training Manual for WHO Multi-Country Study on Women's Health and Domestic Violence. 
Scientific Research Publishing (SCIRP) is one of the largest Open Access journal publishers. It is currently publishing more than 200 open access, online, peer-reviewed journals covering a wide range of academic disciplines. SCIRP serves the worldwide academic communities and contributes to the progress and application of science with its publication.

Other selected journals from SCIRP are listed as below. Submit your manuscript to us via either submit@scirp.org or Online Submission Portal.
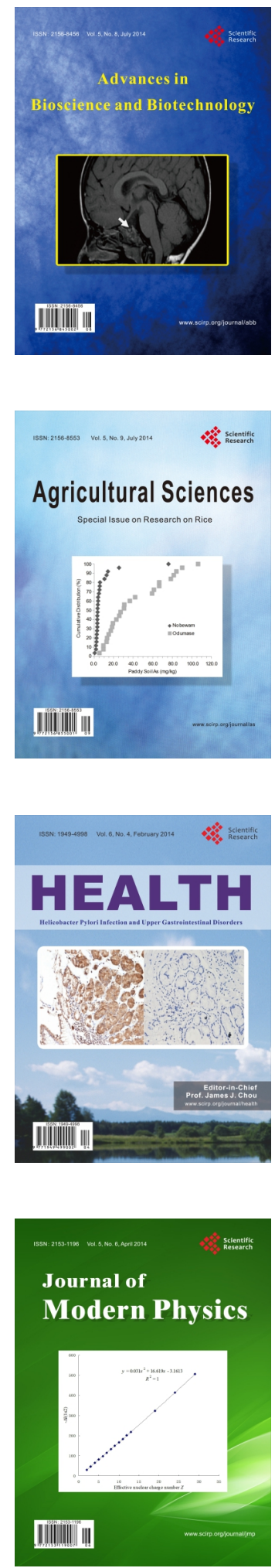
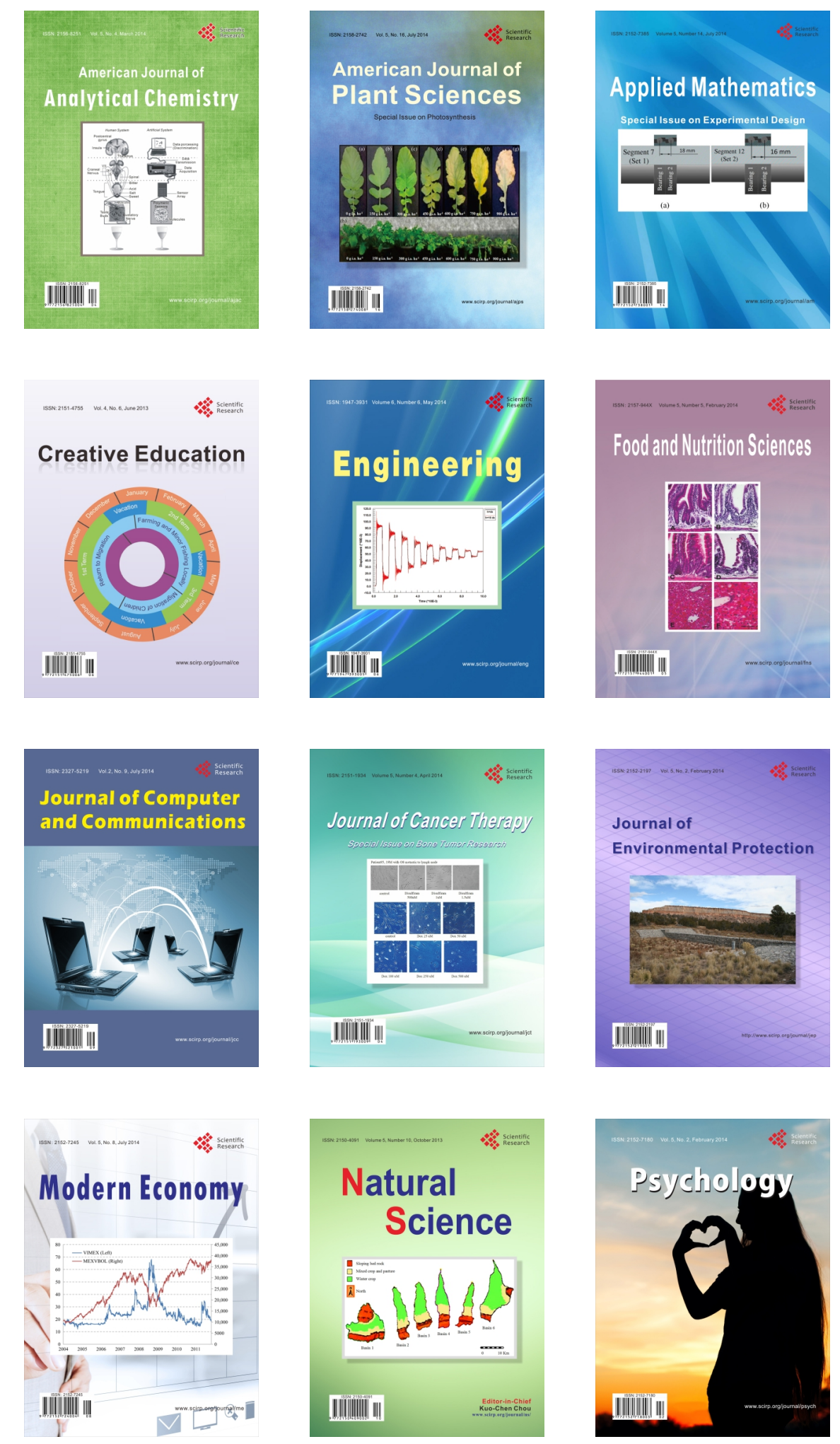